\title{
From Mutual Hedging to All-Round Competition - The Strategic Transformation of Sino-US relations
}

\author{
Yang Meijiao \\ Correspondence: PHD candidate of Peking University, China
}

Received: July 25, 2020 Accepted: August 25, 2020 Online Published: August 26, 2020

doi:10.5539/res.v12n3p88

URL: https://doi.org/10.5539/res.v12n3p88

\begin{abstract}
Since the 21st century, the United States has gradually felt the insecurity brought by structural pressure, and then shifted its strategic focus to the Asia-Pacific region. The Obama administration put forward "Pivot to Asia", and Trump has abandoned the legacy of the previous administration and constructed his own discourse system. He put forward the "Indo-Pacific strategy", which has been expanded in both degree and contents. Meanwhile, China has taken a variety of corresponding strategies respectively. These include the Belt and Road Initiative and a community with a shared future for mankind and the strategic thought of major country diplomacy with Chinese characteristics. These two countries' communicating model has changed from mutual hedging to all-round competition. With the change of US Asia Pacific (Indo-Pacific) strategy, this article uses the neoclassical realism theory to analyze them in detail, and analyzes the factors that influence the change of US strategies and the transformation of Sino-US relations from the system level, the national level and the individual level. Apart from that, their comprehensive competition has added challenges and difficulties to the construction of coordination, cooperation and stability.
\end{abstract}

Keywords: pivot to Asia, Indo-Pacific Strategy, Belt and Road Initiative, mutual hedging, all-round competition

\section{Introduction}

Since the end of the Cold War, the bipolar world pattern has been disintegrated and a number of burgeoning forces gradually emerged in different regions of the world forming the so-called "one super and many strong" situation. However, with the further strengthening of the influence and economic strength of powerful countries, the United States has turned to be under somewhat pressure from the changing system. Especially the development of China brought a sense of insecurity to the United States (Glaser, 2011). ${ }^{1}$ It then shifted its strategic focus to China's periphery: the Asia-Pacific region has become the main "battlefield" of Sino-US competition, whether to suppress or to hedge China.

China and the United States are the two largest economies in the world. The reason why the United States worries about its hegemonic position is precisely because of China's growing international influence. Sino-US relations not only have an impact on itself, but also on other countries in the world. Many international problems in today's world revolve around Sino-US relations. Even if the countries concerned are not China and the United States, the indirect role of China and the United States cannot be ignored. For example, the strategies of Southeast Asian countries, Japan's national strategy, South Korea's military relationship, EU's foreign behaviors, Russia's international attitude, and African countries' foreign policy all reflect the influence of China and the United States. There are differences in ideology between China and the United States. In modern times, though, ideological differences are not the only and main factor that determines national contradictions. However, the history of competition between the United States and the Soviet Union during the Cold War makes people realize that ideology plays a very important role in countries' cognition of each other. From this point of view, Sino-US relations will influence the development trend of the whole international politics. The competition and cooperation between China and the United States can always rise to the level of global issues.

In 2010, China overtook Japan to become the world's second largest economy. As the largest socialist country, China has shown growing impacts on many aspects. Ideological differences and China's economic achievements make western countries such as EU and the United States full of worries about China's development in different degrees and at different levels (Bader, 2012). At the 19th APEC summit in 2011, the Obama administration put forward the strategies of "Asia-Pacific Rebalance" or "Return to Asia-Pacific", showing a subtle tendency of the United States to restrain China. But at that time China was still on the way to be an influential power, rather an actual one. So the United States has

\footnotetext{
${ }^{1}$ In the 1990s, the "China threat" theory began to prevail. The deepening implementation of China's Belt and Road Initiative has enhanced China's regional and international influence.
} 
adopted hedging strategies against China, using cooperation and competition as two policy tools to deal with China (Medeiros, 2005). However, as the Trump administration came to power and the structural pressure felt by the United States has further intensified, these two countries has gradually turned to a situation of full competition. The Sino-US trade war is one of the typical manifestations. "Indo-Pacific strategy" is the core strategic embodiment of full competition between them. Both the "Return to Asia-Pacific" and the "Indo-Pacific Strategy" are the geopolitical responses of the United States based on international changes.

The shift of US strategy from hedging China to full competition with China is a major change in the current international community. A detailed analysis of the mechanism of international relations behind the change in US Asia-Pacific strategy is of great significance for us to understand the current international situation and is also conducive to a deeper control of the evolution of the world development. In the second part we will analyze the theoretical framework that affects the transformation of US Asia-Pacific strategy. Based on neoclassical realism theory, it puts forward two key variables: system pressure and national strategy selection. Specifically, in the case of the United States, national strategy selection is mainly influenced by three elements including US global strategy preference, domestic welfare demand and leadership style. The third part is about cases which will explain in detail how the variables have changed the U.S. strategy in reality. Then the essence and influence of different strategies are analyzed, and the similarities and differences between the two strategies are compared to find out the logical clues. The fourth part is conclusion and policy recommendations. The change of US Asia-Pacific strategy is not groundless, nor the US government's "same old stuff", but has its rigorous mechanism of international relations to play a role. Facing the situation of full competition in Sino-US relations, both China and the U.S. should take a series of accurate, appropriate, positive and effective measures to deal with it and strive to help Sino-US relations to coordination, cooperation and stability.

\section{Theoretical Framework}

In international relations, there are lots of literatures about the factors that affect state behavior. In the traditional cognition, the state is rational and its purpose is to maintain and expand power. Realists believe power determines the states' interests. Human's will to power also has important influence on that (Hans, 1989). While structural realists believe the structure was the decisive factor affecting the behavior of the state. The difference in structure does not lie in the difference in characteristics or functions of units, but in the difference in unit capabilities (Kenneth, 1979).Neo-classical realism combines different factors together, such as the system factor, state factor and individual factor. This theoretical model analyzes the variables that affect state behaviors more accurately and comprehensively. It explains that state behavior and state decision-making are multiple and complex processes. This is not only the result of system elements, but also the comprehensive reflection of various factors within the country. Different countries' types, national capabilities with different strengths and weaknesses, and the characteristics of different regions will have important influences. Though faced with similar international challenges, different countries will have different emphases in the process of cognition, decision-making and policy implementation, and their behavioral responses will be quite different(Yunxiang;Meijiao,2020). But signals of the international system to the country are not always so clear to identify, and leaders may not be able to accurately control them. It's more difficult for them to make rational and scientific decisions all the time. Apart from that, the national capacity is another factor that needs considerations. So "recovering the state" is necessary (Ripsman,N; Taliaferro,J; Lobell,S,2016).

From the analysis of the process of state behavior, the model of neoclassical realism covers more comprehensive levels of analysis and more diverse elements of participation, but there are still some questions. These four variables selected by neoclassical realism somewhat overlap with each other. The distinction is not clear in the influence of variables is in many ways. There is no inevitable cause and effect among national policy response, international result and system stimulation. Therefore, it is necessary to reconstruct the model according to the existing theoretical basis and the reality of international politics. This paper has constructed a theoretical framework for the adjustment of U.S. Asia-Pacific strategy in combination with U.S. national characteristics and the international reality. Specifically, its theoretical framework is as follows: 


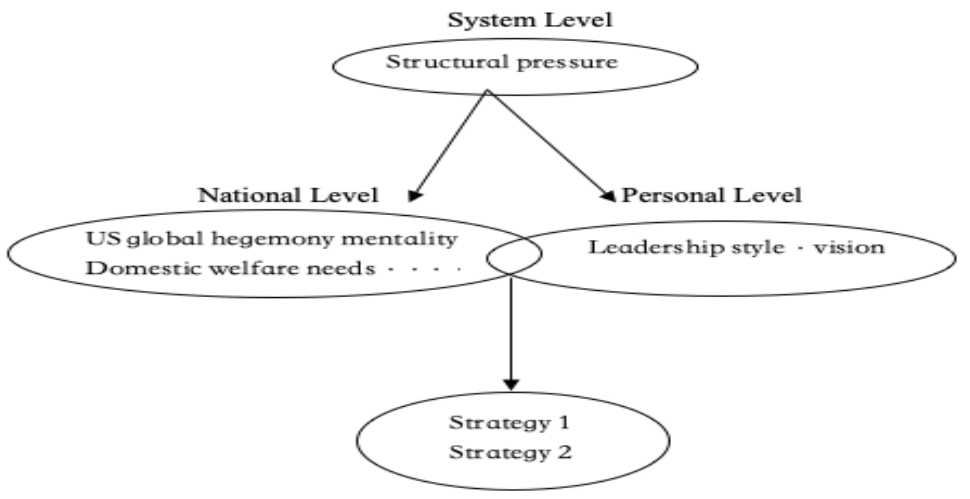

Figure 1. The Theoretical Framework of Causal Logic of State Behavior ${ }^{2}$

When the changes in the environment of the international system happen in a country's system or structural pressure, the country may first consider its own global strategy, especially for super powers. In addition, the specific domestic pressure currently facing the country is also an important factor for its strategic adjustment. It is relatively time-sensitive and is also an effective way for leaders to accumulate political capital. The style of leaders is also a key factor in analyzing state behavior. In the past, People used this factor to analyze autocratic countries, because for such countries, the influence of leaders is more important in the process of making decisions on policy behavior. However, in fact, the same is true in democratic countries, where presidential countries endow presidents with lots of major powers. The personal style of leaders plays an important role in national strategy, whether in the negotiation process or in the decision-making process (Jervis, 1976).

As the system pressure changes, it can have different influences for big powers, small and medium-sized powers. When leaders respond positively to threats, the competition in its national strategy will increase in the face of rising powers, and the ranking position of the state in the international community is the most important part of the domestic factors. The international position affects the strategic trend of a country greatly. Because of its different position in the international community, the foreign policy of a country can be different. Although in democratic countries, elections are almost never decided by foreign policy issues, foreign policy occupies an important topic every time. For example, Trump's election was conducted under the slogan of "Making America Great Again".

\begin{tabular}{|c|c|c|c|c|}
\hline \multirow{2}{*}{\multicolumn{2}{|c|}{$\begin{array}{l}\text { Influencing } \\
\text { and Dynamic } \\
\text { andors }\end{array}$}} & \multicolumn{3}{|c|}{ Responses of Different Types of Countries to National Strategies } \\
\hline & & $\begin{array}{l}\text { big countries with } \\
\text { stakes }\end{array}$ & $\begin{array}{c}\text { Small and } \\
\text { Medium-Sized } \\
\text { Countries with Stakes }\end{array}$ & Uninterested countries \\
\hline \multirow{2}{*}{$\begin{array}{l}\text { System } \\
\text { pressure }\end{array}$} & $\uparrow$ & Competition $\uparrow$ & hedging $\downarrow$ & - \\
\hline & $\downarrow$ & Competition $\downarrow$ & hedging $\uparrow$ & - \\
\hline \multicolumn{2}{|c|}{$\begin{array}{l}\text { Attitude towards } \\
\text { International Status }\end{array}$} & Competition $\uparrow$ & - & - \\
\hline \multirow[b]{2}{*}{$\begin{array}{l}\text { Domestic } \\
\text { welfare } \\
\text { needs }\end{array}$} & Urgency $\uparrow$ & Competition $\uparrow$ & hedging $\uparrow$ & - \\
\hline & $\begin{array}{c}\text { Urgency } \\
\downarrow\end{array}$ & - & hedging - & - \\
\hline \multicolumn{2}{|c|}{ Leadership style } & Competition $\uparrow$ & hedging $\uparrow$ & - \\
\hline
\end{tabular}

Figure 2. Different Responses of Different Types of Countries to the changes $1^{3}$

Note : $\uparrow$ indicates enhancement, $\downarrow$ indicates decline, — indicates no obvious change.

China's regional and global influence is expanding as China's economic strength increases and its integration into the

2 This figure is made by the author.

${ }^{3}$ The figure is self-made by the author. 
framework of global governance continues to accelerate. As the only hegemonic country in the world, the United States can feel tremendous systematic pressure from any possibility that may challenge its ranking. At the same time, at the national level, The United States has always had the sense of superiority of " Manifest Destiny "and "America first", and it will never allow other countries to surpass it, that is, the "hegemonic mentality" in the United States global strategy. In addition, Trump's realistic thinking has profoundly changed American strategy. Under the increasingly fierce competition between China and the United States, a trade war broke out between these two countries. This is not only reflected in the economic field, but also spread to agriculture, science and technology, humanities exchanges and other fields. And in terms of global strategy, Trump has proposed the "Indo-Pacific Strategy" to enhance the influence of the United States in the Asia-Pacific region and tried to expand to the Indian Ocean region. From the following comparison of the strategies of the two governments, it can conclude that the U.S. has shifted its strategy of hedging China from the Obama era to the strategy of containing China. Sino-U.S. relations have entered a state of full competition. How has the U.S. national strategy achieved a smooth transition and a smooth landing? What are the contents and impacts of different strategies? We can find the answer in the next part.

\section{Cases}

2020 is the 41th anniversary of the formal establishment of diplomatic relations between China and the US. Among those years, with changes in the international society, both China and the United States have passed smoothly and have continued to exert greater influence in the region or in the world. In particular, the performance of Asia and the development of China are all the more remarkable. Asia is already one of the most dynamic and potential regions in the international community nowadays. According to the research, in the past ten years, 60 percent of the contribution of global economic growth came from Asia, while China's annual economic growth accounted for about 30 percent of the world's becoming the country that made the greatest contribution to the world's economic growth. Moreover, China has also actively joined international organizations and multilateral cooperation frameworks to continuously expand China's international discourse system. Especially since "The Belt and Road Initiative", China has started to promote regional economic progress as an important advocate. Although as early as 2017 , when Trump paid a state visit to China, Xi Jinping proposed that "the Pacific Ocean is large enough to accommodate China and the US", believing that both sides should manage their differences and jointly promote peace, stability and prosperity in the Asia-Pacific region. But actually for the US, as long as China is there being strong, The United States can always feel insecure and anxious about the possibility of losing its dominance, which is a typical thinking for countries in anarchy. Starting from 2011, the two U.S. administrations has taken the Asia-Pacific region as their strategic focus and successively put forward "Return to Asia-Pacific" or Pivot to Asia and "Indo-Pacific strategy". Next, it will analyze the process of U.S. strategic adjustment in detail.

\section{(1) Pivot to Asia}

After the disintegration of the Soviet Union, the original bipolar world pattern was broken, forming a dominant situation in the United States. From the end of Cold War to the first ten years of the 21st century, the Asia-Pacific region, which is full of development vitality and great growth potential, has not received enough attention. But with the Chinese rising momentum and rapidly growing influence, it has attracted the attention of the United States to a varying degree. The territorial disputes in the Asia-Pacific region and the South China Sea issue have made the US realize the need to shift its strategic focus and control the development trend of the Pacific Ocean. The development and changes in the Asia-Pacific region have continuously changed the traditional geopolitical situation. The U.S. politicians and scholars have also begun to turn their eyes to Asia-Pacific and made their Asian strategy operational. Only then did the United States formally shift its strategic focus to the Asia-Pacific region and put forward the strategy of "Return to Asia-Pacific" or Pivot to Asia.

At the 19th APEC summit in November 2011, Obama put forward the strategy of "Return to Asia-Pacific", saying that Iraq and Afghanistan no longer involved major U.S. forces and would shift the focus of future strategy to Asia-Pacific. This was mainly reflected in Hillary's first visit as secretary of state. Instead of choosing Europe, Hillary's first visit was unexpectedly set in Tokyo, Seoul, Beijing and Jakarta in Asia, pointing out that the United States would expand its role in the Asia-Pacific region and strengthen its partnership with Asia-Pacific countries. Later in 2012, Obama expressed his views on the new U.S. defense strategy report at a press conference with Defense Secretary Panetta and Chairman of the Joint Chiefs of Staff, noting the U.S. would halve its military presence in the Middle East, form a partnership with countries in a wider range of the world, and further increase its strategic deployment in the Asia-Pacific region. Meanwhile they would deploy key regional force of the United States to this region in the future (U.S.Department of Defense, 2012). At the 11th Shangri-La Dialogue and Asian Security Conference, U.S. Defense Secretary Panetta reiterated Obama's "Asia-Pacific Rebalance" strategy, saying that the United States would transfer 60 percent of the U.S. warships to the Pacific Ocean by 2020, while the Air Force Center would gradually move to the Pacific Ocean to further operationalize the new U.S. defense strategy. 
In March 2013, Thomas E. Donilon, Chief Security Adviser of the White House of the United States, delivered a report named "The United States and the Asia-Pacific in 2013" at the Asian Association's seminar with the theme "Asia: Beyond the Headlines." In this report, Donilon elaborated the steps and measures of US Asia-Pacific rebalancing. He believed that the current time was an important transition period in Asia. In this changing situation, US rebalancing is particularly important, and further elaborated the specific steps of US "Asia-Pacific Rebalance"(The White House, 2012). Since then, the top echelons of the Obama administration have expressed their views on the "Asia-Pacific Rebalance" on different occasions and said they would fully push forward the implementation.

How did the U.S. government implement the "Asia-Pacific Rebalance" strategy in addition to the publicity of these policies and instructions? The following will sort it out militarily, economically and politically.

\begin{tabular}{|c|c|c|}
\hline & Measures & Consequences and effects \\
\hline Politically & $\begin{array}{l}\text { To strengthen alliances with the five } \\
\text { Asian-Pacific countries; } \\
\text { To strengthen relations with Singapore, India, } \\
\text { Indonesia, Vietnam and Myanmar; } \\
\text { To join the "ASEAN Treaty of Friendship and } \\
\text { Cooperation" and participate in the "ASEAN } \\
\text { Summit" in 2009; } \\
\text { To become a strategic partner with ASEAN in } \\
2015 \text {; }\end{array}$ & $\begin{array}{l}\text { The circle of friends of the United States in } \\
\text { the Asia-Pacific region has further } \\
\text { expanded. } \\
\text { In the framework of bilateral or multilateral } \\
\text { cooperation, U.S. influence is everywhere. }\end{array}$ \\
\hline Economically & $\begin{array}{l}\text { To take TPP as the center of US Asia-Pacific } \\
\text { economic strategy. In 2009, the United States } \\
\text { joined the TPP negotiations and took the lead } \\
\text { in changing the "Trans-Pacific Strategic } \\
\text { Economic Partnership Agreement" to } \\
\text { "Trans-Pacific Partnership Agreement". The } \\
\text { partnership circle was further expanded to } \\
\text { negotiate and cooperate on issues such as } \\
\text { tariffs, e-commerce, clean energy and } \\
\text { intellectual property rights. } \\
\text { the "US-ASEAN Initiative to Expand } \\
\text { Economic Cooperation (E3)" launched In } \\
\text { 2013. } \\
\text { TPP Trade Agreement Reached in 2015; }\end{array}$ & $\begin{array}{l}\text { To a certain extent, it has promoted } \\
\text { economic and trade cooperation in the } \\
\text { Asia-Pacific region. } \\
\text { The United States overemphasizes its own } \\
\text { geopolitical strategy, neglects the common } \\
\text { interests of economic development and } \\
\text { integration of various countries, and even } \\
\text { pushes the relationship between the two } \\
\text { into opposition. TPP is in many cases a } \\
\text { U.S.-led issue, and its degree of fit with the } \\
\text { Asia-Pacific region is not so high. }\end{array}$ \\
\hline Militarily & $\begin{array}{l}\text { Starting in 2012, the United States deployed } \\
\text { marines to Darwin base in Australia. } \\
\text { In 2013, the United States and Japan held a } \\
\text { Security Consultation Committee }(2+2) \text { to } \\
\text { strengthen defense cooperation. } \\
\text { US Deployed Warships in Singapore Changi } \\
\text { Port in 2013; The United States deployed } \\
\text { cruisers, command ships, minesweepers and } \\
\text { other fleets at Pearl Harbor Base, Yokosuka } \\
\text { Base and Sasebo Base. } \\
\text { The 21st Century Maritime Forces } \\
\text { Cooperation Strategy was released in } 2015 . \\
\text { US Deployed "THAAD" System in South } \\
\text { Korea in 2016; }\end{array}$ & $\begin{array}{l}\text { Increased tensions in the Asia-Pacific } \\
\text { region; } \\
\text { Caused further deterioration of Sino-US } \\
\text { relations; }\end{array}$ \\
\hline
\end{tabular}

Figure 3. Measures and Impacts of "Asia-Pacific Rebalancing" Strategy ${ }^{4}$

To some extent the "Asia-Pacific Rebalance" stems from America's strategic anxiety. Rumors of a "post-U.S. era" has kept cropping up. On the one hand, terrorism is hard to eradicate, which is a potential safety hazard to the world. On the other hand, the strong development momentum in the Asia-Pacific region and the possible structural changes caused by

${ }^{4}$ Figure 3 is synthesized by the author. 
China's rapid rise have all aroused deep worries in the United States(Zongze Ruan,2014). The "rebalancing" strategy of the United States is not only to ease anxiety, but also to eliminate panic over changes in the international structure. What the United States is currently facing is a dynamic picture full of uncertainty and unpredictability. State actors and many non-State actors are intertwined, while power is increasingly dispersed. Therefore, some people think that the United States needs to carry out a great-power balance and play a full-scale game with China in the Pacific Ocean, such as military deployment in the waters of the First Island Chain, geo-military game with China, deployment of "military base chain" in maritime connectivity and other economic games. At the same time, the United States advocates "freedom of navigation" in the waters around China, curbs China's maritime claims, and plays geo-political games (Huaigao, 2019).

With the advancement of the "rebalancing" strategy, established US allies have strengthened their relations with the US. Other Southeast Asian countries have also gained more security from US military deployment. However, China's regional influence in economic development can to some extent compete with US military support. Especially since the implementation of The Belt and Road Initiative, this has led many ASEAN countries to choose hedging strategies, relying on China economically and the US militarily. From this part, the US attempting to "create" the US Pacific century through "rebalancing" is not so effective(Lye,2004). In January 2017, Trump vowed to withdraw from TPP on the very same day. The framework originally used to be the backbone of the U.S. government's Asia-Pacific strategic economy was eclipsed by the new administration. In March 2017, the U.S. assistant secretary of state said that the "Asia-Pacific Rebalance" strategy was over. The Trump government put forward new strategic concepts and strategic discourse. Since then, the "Asia-Pacific Rebalance" strategy has come to an end. The U.S. strategy in the Pacific has emerged in a new form, which is the Indo-Pacific strategy.

\section{(2) Indo-Pacific Strategy}

The concept of "Indo-Pacific strategy" originated from the "Indo-Pacific region", which is a geopolitical concept and first appeared in the 2007 Indian navy captain's strategic analysis report (Gurpreet, 2007). Later, during his visit to India, Japanese Prime Minister Abe said that the Indian Ocean and the Pacific Ocean shared common freedom and prosperity, and also faced the common challenges brought by the new era. The relevant countries should focus on a broader Asian perspective. In 2013, some scholars issued a document pointing out that as the United States shifted its strategic focus to the Asia-Pacific region, India's position in the U.S. strategy would become more important and the Indo-Pacific region would emerge as a new regional hotspot (Mishra, 2013). Scholars from different countries have also continuously expressed their understanding of the Indian-Pacific region. In 2013, this concept was formally written into the Australian Defense White Paper 2013. So far, the "Indian-Pacific region" has been continuously used in government official documents or scholars' reports of some countries. In 2017, U.S. Secretary of State Rex Tillerson mentioned the concept of "Indo-Pacific" 15 times in one report, stating Japan and Australia should unite and cooperate to confront China's challenge to international rules. Two weeks later, Trump replaced the concept of "Asia-Pacific" with the concept of "Indo-Pacific". Trump visited two cities in Vietnam during his Asian tour, hoping to strengthen the partnership with Vietnam and weaken China's influence in this region. Some scholars believed that was aimed at confronting the rising China (Jaipragas, 2017).

Not until November 2017, Trump formally proposed the "Free and Open India-Pacific Strategy" (FOIPS) at the 25th APEC summit in Vietnam. Since then, the "Indo-Pacific strategy" has officially replaced the "Asia-Pacific Rebalance" of the Obama era as the strategic slogan of the new administration. The strategy covers a much larger area than the traditional Asia-Pacific region and aims to strengthen the political freedom, economic and trade cooperation, military dialogue and other fields in the Indo-Pacific region. From the end of 2017 to the beginning of 2018, the United States successively issued the National Security Strategy Report and the National Defense Strategy Report, summarizing the "Indo-Pacific Strategy" from a macro level. In May 2018, US Defense Secretary James N. Mattis changed the United States Pacific Command to the United States Indo-Pacific Command. Then at the end of 2018, the U.S. Congress passed the Asian Reinsurance Initiative Act of 2018, which further concretized the relevant vision of the "Indo-Pacific Strategy".

Although Tanaka believed Trump's "Indo-Pacific Strategy" was still an abstract concept when BBC interviewed former Japanese Deputy Foreign Minister Tanaka in 2017, since then, the United States has been implementing this strategy intensively. In June 2018, the U.S. Department of Defense released the Indo-Pacific Strategy Report, which elaborated on the specific content of the "Indo-Pacific Strategy". The report regards China as a revisionist power that undermines regional stability and prosperity. Under the keynote of containing China's rise, the United States starts its strategic deployment from the politics, military and economy. In addition, the report also includes topics such as science and technology and the Internet. It is obvious from this report that the purpose of the "Indo-Pacific Strategy" of the United States is to describe China as a destroyer of regional security and to lead Indo-Pacific countries to resist China's rise. Compared with Indo-Pacific's security, stability and prosperity, the real purpose of the United States is to maintain its hegemony, continue to monopolize international discourse power and have indisputable dominance in international 
affairs. For one thing, countries like India and Japan hope that their foreign policies can be less influenced by the United States, and for another they hope to use the influence of the United States to counter the rise of China.

Apart from that, the United States has further formulated its vision for the Indo-Pacific region through the promulgation of a formal law, namely, the Asian Reinsurance Initiative Act of 2018 in December 2018, which aimed to strengthen the leadership of the United States in the Indo-Pacific region. The United States would provide security reassurance to its allies in this region, and meanwhile it showed its determination to dominate the Indo-Pacific partner countries. In order to strengthen its relations with the Indo-Pacific countries, the Act recommended that the United States government allocate US\$ 1.5 billion for deployment for five years, while at the same time strengthen the US-Taiwan relations and regularly sell defensive weapons to Taiwan. The law seriously violated the three Sino-US joint communiques and the one China policy. Although the Chinese government expressed strong opposition, the United States still pushed forward the implementation of the law.

In August 2019, U.S. Secretary of State Pompeo delivered a speech on the 52nd anniversary of the founding of ASEAN, believing that the strategic partnership between the United States and ASEAN would help to promote Indo-pacific prosperity. This region would be open, inclusive and reflect the original rule order (Pompeo 2019). Although former U.S. Deputy Secretary of Commerce Frank Lavin didn't not believe that the "Indo-Pacific Strategy" and "The Belt and Road Initiative" must be in a state of conflict and confrontation, he expressed concerns about China's rise. In September 2019, the United States and ASEAN countries held the first joint maritime military exercise (AUMX) in the Indo-Pacific region, involving about 1,000 military personnel. The U.S. Rear Admiral Joey Tynch held that the exercise combined the strength of ASEAN, the strength of the U.S. Navy, and the common belief in a free and open Indian Ocean-Pacific to create a safer maritime environment. Though this exercise was only a military cooperation between the United States and ASEAN, its political significance was far greater than that. This move has made U.S. allies in the Indo-Pacific region more firmly follow the footsteps of the US, and has also encouraged some countries that have conflicts with China more confidently.

On November 4, 2019, the United States suddenly issued the report " A Free and Open Indo-Pacific: Advancing a Shared Vision ". It would go deep into the Indo-Pacific region and jointly safeguard the free and open regional order of this area with its allies and partners. Since Trump came to power, the U.S. government and the United States Agency for International Development (USAID) have invested 4.5 billion dollars in foreign aid to the region, and will continue to develop new investment projects and build partnerships with more countries. The United States believes that the countries in Indo-Pacific are currently threatened by some "revisionist" countries to the sovereignty, prosperity and peace of the countries in the region (implying China, Russia and North Korea, with particular emphasis on China).

From the proposal of the "Indo-Pacific Strategy" to its further definition and concrete implementation, it can be concluded that the system pressure felt by the now United States is much greater than that of the Obama era, while the United States' ambition to maintain its global hegemony is the same. It is the "Marshall Plan" that gave Europe a hand after World War II, or the war that started in the Middle East during Bush's reign, or the creation of "America's Pacific World" in the Indo-Pacific region now, which all show that the United States is constantly adjusting to the changes in the regional situation under its consistent hegemonic mentality. The two economic crises after the Cold War caused a certain degree of recession in the U.S. economy. Trump's pragmatic thinking has stimulated the strategic shift of the U.S. people and government.

\section{(3) Comparison Between "Pivot to Asia" Strategy and "Indo-Pacific Strategy"}

Neo-classical realism theory holds that the emergence or transformation of state behavior is based on the stimulation of the external system on the prism of the state. That is to say, policy making needs to go through a series of complex intermediate variables. However, in this analytical framework, the "black box" of the state has been opened, and many domestic factors have had a clearly important impact on state behavior. The above parts have analyzed in detail the development of Obama's "Pivot to Asia" strategy and Trump's "Indo-Pacific strategy" earlier. Next, it is necessary to make an international political comparison between the two strategies. Only in this way can people have a clearer understanding of how the United States having changed from its previous hedging strategy to full competition with China. The following will also further analyze the changes in the international situation reflected in hedging strategy and full competition.

From a macro perspective, the United States adopted a hedging strategy against China during the Obama administration, while China adopted an anti-hedging strategy against the United States. As early as the beginning of the 21st century, Richard Weitz predicted China's potential roles in East Asia's security system in the next 20 years by analyzing its relative military capabilities and foreign policy intentions. He believed that China might play one of the four roles in the future, namely, an enemy, a potential threat, China being annoying and China not having threats. Then he pointed that China should be contacted by balancing policies or hedging policies. Hedging policy could be adopted when balancing 
China failed (Weitz,2011).But China's outstanding performance has made the US more and more unsecure. From 1990 to 2010, China's gross domestic product increased by more than 20 times, and the total import and export of goods increased by about 35 times. From 2004 to 2010, China's net foreign direct investment increased by more than 11 times in a few short years.

Unit (100 million yuan)

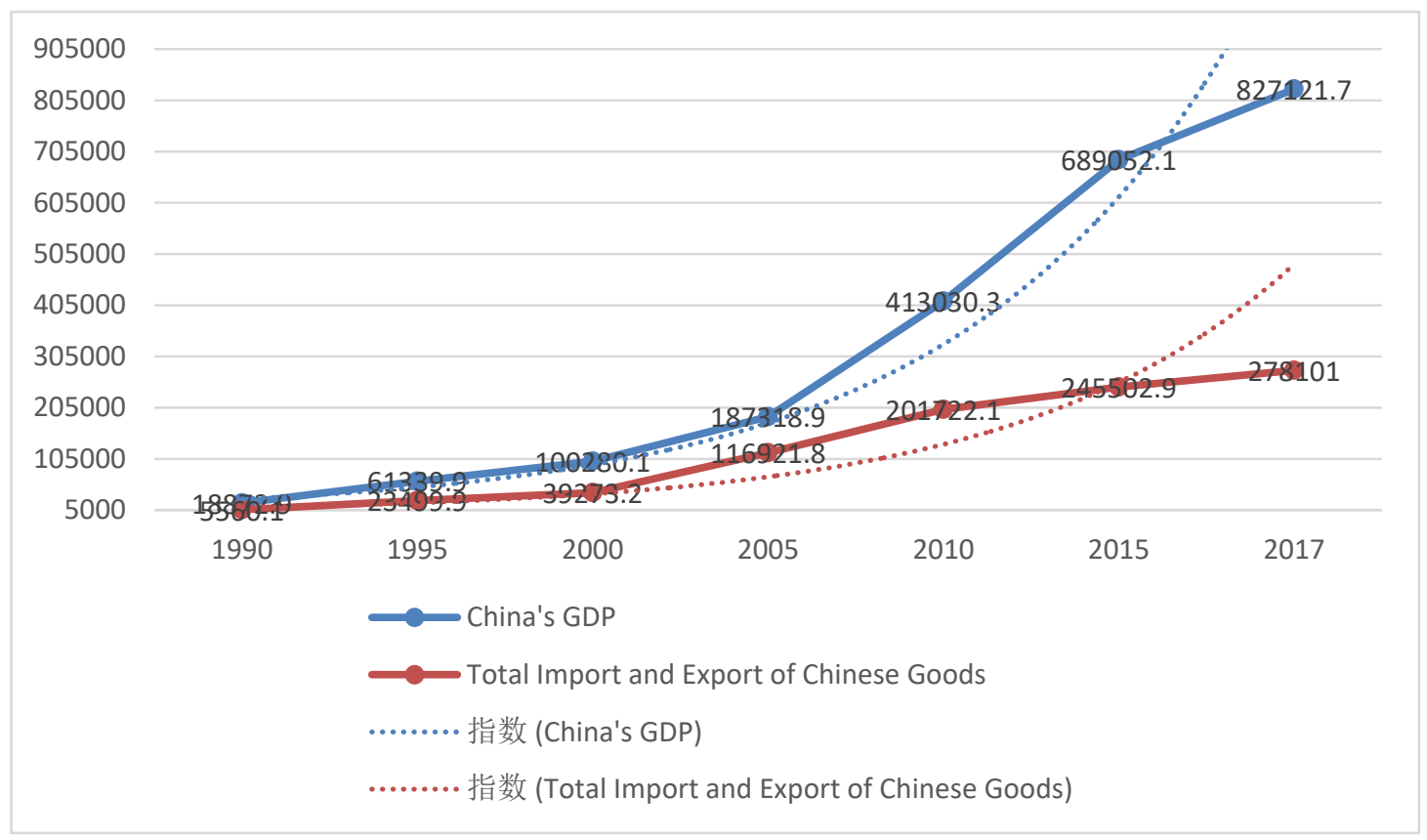

Figure 4. China's GDP and Total Import and Export of Goods from 1990 to $2010^{5}$

But by Trump's time, China and the United States have entered an all-round stage of competition. This is mainly because China's development has led the United States to believe that China is challenging U.S. hegemony and undermining the U.S.-led international order, whether economically, politically or militarily. In terms of economy, China's gross domestic product accounted for 1.8 percent of the world's total at the beginning of the reform and opening up, but this proportion had grown by 16.1 percent by 2018. Judging from the world ranking of total economic output, China has surpassed France, Germany and Japan to become the world's second largest economy. Some reports predict that China may surpass the United States to become the world's largest economy in 2027.(Ren Zeping, 2019) On the political front, China has established partnerships with many countries in the Asia-Pacific region and has actively joined regional multilateral framework agreements. From 2011 to December 2018, China has joined 69 multilateral framework agreements in eight years, covering a wide range of topics, including ocean, environmental protection, security, economic and trade, and cultural exchanges.

In addition, the conflict in the South China Sea is also an important link in China's communication with Asia-Pacific countries. China's claim to the South China Sea has stimulated the United States and the related South China Sea island claimants, making the United States believe that China is vying for regional leadership in the Asia-Pacific region. On the military front, China's military expenditure has increased year by year, especially since 2005. Although China's military expenditure is lower than that of the United States, its armed forces far exceed that of the United States. According to the judgment of the situation, the "Indo-Pacific Strategy" of the United States has entered a concrete stage of implementation and has begun to take measures to effectively curb China's further development.

From the micro level, the U.S. global hegemonic mentality, its rising unemployment rate and the different ruling styles of Trump and Obama all play a very important role in the U.S. national strategy from hedging to fully competing with China. No matter in the Obama or Trump administration, there has been no fundamental change in the U.S. global hegemonic ambition. They all believe that the U.S. has a natural exception and is unique in the world system. From the "Fourteen Points" "Four Freedoms" "The New World Order" to "Return to Asia-Pacific" and "Indo-Pacific strategy". Whatever the background of the times America is in, its ambition to dominate the world and maintain this system has not changed. The

\footnotetext{
${ }^{5}$ The figure is self-made by the author, and the data comes from the National Bureau of Statistics of China,http://www.stats.gov.cn/tjsj/ndsj/ (accessed on 5 December 2019).
} 
Trump administration specifically elaborated the "America First" concept to Davos' elites at the 48th World Economic Forum. Although the elites attending the meeting and the relevant people in other countries and regions hoped that the United States would assume more key responsibilities, the United States laid more emphasis on condemning China and the world leadership when expressing its strategic thinking. But in the Trump era, the United States' strategy (Indo-Pacific strategy) is more mature and operational.

In terms of domestic welfare demands, China and the United States started a trade war in 2018. Trump thought that the America's trade with China had a huge trade deficit, with an annual reverse difference of up to $\$ 500$ billion. In addition, the US lost about $\$ 300$ billion in intellectual property rights. The president wanted to end this situation and gained good administrative reputation (Dwutsche,2018).The U.S. Trade Representative Office said that the U.S. trade deficit with China was larger than the sum of the U.S. trade deficits with Mexico, Germany and Japan. The U.S. trade deficit with China was $\$ 337$ billion, while the sum of the U.S. trade deficits with the three countries was \$ 193 billion. Therefore, the United States has got to impose a 25 percent tariff on 1,330 items of nearly $\$ 50$ billion of goods that China exported to the US. China subsequently responded by imposing the same tariff on 106 items of 14 categories of goods in the United States.(Xinhuanet, 2018) Although on the face of it , it is due to the US government imposing tariffs on the goods planned in the "Made in China 2025" plan. The plan was formulated by the Chinese government and its essence is the US has used the trade war as an excuse to find a "reasonable" way for its strategic transfer to bind China. The US also listed some Chinese enterprises and institutions on the "entity list" in June 2019, including those in the super-calculation field, and stipulated that the entities on the "entity list" were prohibited from purchasing US parts without the approval of the US government. This was a further restriction and containment of China from the aspect of science and technology. Compared with the Obama administration, It can be seen that Trump has used conflicts in economy and trade, science and technology, intellectual property rights and other aspects to serve its deeper strategic purpose. Till then containing China has become the top priority of the United States.

Waltz used analytic hierarchy process (AHP) for understanding the conflicts in the world community. His book "Man, State and War" analyzed the origin of war according to the three levels of international system, state and individual. He believed that human nature was the root of war and needed to explore the relationship between man, war and national system from a deep level (Waltz,2001). While Jervis believed that "personal experience, early adult experience, and events affecting individuals and their countries all have a significant impact on a person's later perceptual tendencies"(Jervis,1976).Leaders play an important role that cannot be ignored in national decision-making, but different people can have different emotional reactions. According to the effect of strong personal emotions, people's perception is easy to make mistakes by the complex situations. Compared with Obama, Trump has always put pragmatism first. Obama followed a more "politically correct" path and did "things that conform to the status of the U.S. president", basically following a "path dependence" on the quite right way of the U.S. president. From this way, Obama has more idealistic tone, while Trump is a clear realist. This can help to understand the difference between Trump's "Indo-Pacific Strategy" and Obama's "Asia-Pacific Rebalance" from another angle.

As a major power in the Indo-Pacific region, India is a country that can't be ignored in Sino-US relations. Sino-Indian relations and US-India relations are both important links in Sino-US competition. India is the pillar of America's Indo-Pacific strategy. The United States has further strengthened its relations with India by signing agreements with India such as GSOMIA, LEMOA, COMCASA and BECA. Moreover, the United States has gradually become one of India's major arms importers. In June 2020, there was a border conflict between China and India, and Sino-Indian relations became tense for a period of time. However, by analyzing a series of India's actions, people can see that India still tries to adopt the hedging strategy between China and the United States. Through military cooperation with the United States, India can effectively enhance its military capabilities and obtain security products. It can also gain huge economic benefits from its cooperation with China. At the same time, India carried out the flexible balancing measures among great powers. It has strengthened economic, trade, military, diplomatic and political cooperation with Russia, Vietnam, Indonesia, Singapore, Japan and Myanmar. The military cooperation between India and Russia is an important part of India's hedging against the United States, and India and Russia have also established a "special strategic partnership". The transformation of Sino-US relations from mutual hedging to comprehensive competition will probably further stimulate India's incentive to adopt hedging strategy. Because only in this way can India gain more development space in the highly unstable and uncertain international society.

\section{Conclusions}

Based on the above analysis, we can clearly see that the U.S. ambition to maintain its global hegemony is increasingly fierce. Externally, the development of China and the rise of its influence have changed the system pressure felt by the United States. The United States thinks that its hegemony space has been squeezed. Coupled with the increase of unemployment rate in the United States, the completely different ruling styles of Trump and Obama, and other factors have all pushed China and the United States from hedging to full-scale competition. The change in the nature of 
competition can be reflected from the "Pivot to Asia" strategy to the "Indo-Pacific strategy", the establishment of TPP to the "Asian Reinsurance Initiative Act of 2018" and the emergence and evolution of the Sino-US trade war. The US. is no longer satisfied with balancing China institutionally and containing China economically. Instead, it has turned into a model of comprehensively binding China in terms of security and imposing economic sanctions on China. Measures against American checks and balances were taken. With the outbreak of the COVID-19, the instability of the international community has intensified. The competition between China and the United States is particularly fierce. Against the background of the epidemic, the implementation of the US Indo-Pacific strategy has added more complexity. China is also competing with the United States in the field of public health through "epidemic diplomacy".

These two countries should open up more space for multilateral cooperation. Any country should not only pursue its own development and strength but also allow the development of the others. They can establish more dialogue mechanisms to jointly deal with new global issues and strengthen defense against terrorism, environmental protection, energy security and piracy. No matter how the international situation changes, peace and stability will always be fundamental. China and the United States should continue to promote international relations based on coordination, cooperation and stability. If the two countries combine they will benefit, and they will both suffer if they fight. More than 40 years after the establishment of diplomatic relations between China and the United States, they should sum up experiences and lessons in exchanges and abandon the zero-sum game thinking. China and the United States both bear different responsibilities to the world. Both need to fully recognize the burdens on their shoulders and focus on making the harmonious international community.

\section{References}

Bader, J. A. (2012). Obama and China's rise: An insider's account of America's Asia strategy. Brookings Institution Press.

Deutsche, W. (2018).China and the United States continue to fight Trump: No trade war. DW. Retrieved from https://p.dw.com/p/2vRUb, (accessed on 20 May 2018).

Glaser, C. (2011). Will China's rise lead to war? Why realism does not mean pessimism. Foreign Affairs, 80-91.

Hans, M. (1989). Politics among Nations: The Struggle for Power and Peace. New York: Alfred A. Knopf.

Huaigao, Q. (2019). Sino-US Maritime Competition in the Western Pacific and Its Influence. Wuhan University Journal (Philosophy \& Social Science), 72(3), 4-15.

Jaipragas, B. (2017). Why is the US calling Asia-Pacific the Indo-Pacific? Donald Trump to 'Clarify'. South China Morning Post, 7.

Jervis, R. (2017). Perception and misperception in international politics: New edition. Princeton University Press. https://doi.org/10.2307/j.ctvc77bx3

Kenneth, W. (1979). Theory of International Politics, Hoboken: Addison-Wesley.

Khurana, G. S. (2007). Security of sea lines: Prospects for India-Japan cooperation. Strategic Analysis, 31(1), 139-153. https://doi.org/10.1080/09700160701355485

Lye, C. (2004). America's Asia: Racial Form and American Literature, 1893-1945. Princeton: Princeton University Press.

Medeiros, E. S. (2005). Strategic hedging and the future of Asia-pacific stability. The Washington Quarterly, 29(1), 145-167. https://doi.org/10.1162/016366005774859724

Ministry of Foreign Affairs of the People's Republic of China. (2019). Speech by Consul General in Chicago at the Seminar of Asia Watch. Retrieved from https://www.fmprc.gov.cn/web/dszlsjt_673036/zls_673040/t1692425.shtml (accessed on 10 November 2019).

Mishra, V. (2013). India and the rise of the Indo-Pacific. The Diplomat.

Panetta, L., \& Obama, B. (2012). Sustaining US global leadership: Priorities for 21st century defense. Washington, DC: US Department of Defense, 1 .

Pompeo, M. (2019) The 52nd Anniversary of the Founding of the Association of Southeast Asian Nations, $\begin{array}{lllll}\text { SECRETARY OF } & \text { STATE, } & \text { Retrieved } & \text { from }\end{array}$ https://asean.usmission.gov/the-52nd-anniversary-of-the-founding-of-the-association-of-southeast-asian-nations/ (accessed on 15 November 2019)

Ren, Z. (2019). Comparison of economic strength between China and America. Global economic research report. Retrieved from http://www.199it.com/archives/887155.html (accessed on 13 July 2019). 
Ripsman, N. M., Taliaferro, J. W., \& Lobell, S. E. (2016). Neoclassical realist theory of international politics. Oxford University Press. https://doi.org/10.1093/acprof:oso/9780199899234.001.0001

The White House. (2012) Remarks by National Security Advisor Tom Donilon, November. Retrieved from https://obamawhitehouse.archives.gov/the-press-office/2012/11/15/remarks-national-security-advisor-tom-donilonprepared-delivery (accessed on 16 November 2016).

Waltz, K. N. (2001). Man, the state, and war: A theoretical analysis. Columbia University Press.

Weitz, R. (2001). Meeting the China challenge: Some insights from scenario-based planning. The Journal of Strategic Studies, 24(3), 19-48. https://doi.org/10.1080/01402390108437844

Xinhuanet (2018). China plans to impose a $25 \%$ tariff on 14 categories of 106 items such as soybeans, automobiles and chemicals of the United States. Retrieved from http://www.xinhuanet.com/fortune/2018-04/04/c_1122639386.htm (accessed on 15 April 2018).

Yunxiang, L., \& Meijiao, Y. (2020). Studying the Development Track and Future Trend of China-Japan Relations from the Four Political Documents. Northeast Asia Forum, 3, 17-29. Retrieved from http://www.cqvip.com/qk/97722x/202003/7101551497.html

Zongze, R. (2014). The U.S.Rebalance toward Asia: Quo Vadis?.World Economics and Politics, No.4.4-20+156. Retrieved from http://www.cqvip.com/qk/92442x/201404/49229232.html

\section{Copyrights}

Copyright for this article is retained by the author(s), with first publication rights granted to the journal.

This is an open-access article distributed under the terms and conditions of the Creative Commons Attribution license (http://creativecommons.org/licenses/by/4.0/). 